\title{
The Interactions of Thiazide Diuretics
}

\section{with Parathyroid Hormone and Vitamin D}

\author{
STUDIES IN PATIENTS WITH HYPOPARATHYROIDISM
}

\author{
A. M. ParfitT \\ From the Department of Medicine, University of Queensland, Royal \\ Brisbane Hospital, Brisbane, Queensland 4029, Australia
}

A B S T R A C T In order to clarify the mechanisms of thiazide diuretic-induced hypocalciuria, the effect of a thiazide was studied for 7 days in seven patients with hypoparathyroidism on Vitamin D and one on calcium infusion, and seven euparathyroid patients with hypercalciuria. In the control group, calcium excretion $(\mathrm{mg} / 24$ hr) fell by $44 \%$ from 415 to 232 within 4 days and remained at this level. Plasma total calcium corrected for total protein did not change. In the hypoparathyroid group, calcium excretion fell by $11 \%$ from 351 to 311 and then returned to the base line level. Plasma total calcium $(\mathrm{mg} / 100 \mathrm{ml})$ increased from 10.09 to 10.88 , 11.29 and 10.77 at the end of the $2 \mathrm{nd}, 4 \mathrm{th}$, and 7 th day of thiazide administration. In the patient having i.v. calcium and no Vitamin D, neither plasma nor urinary calcium changed significantly. In both groups sodium excretion increased on the first 2 days and fell to or below base line level thereafter. Urinary phosphate, magnesium, and potassium increased, plasma phosphate rose, and magnesium and potassium fell. It is concluded that: (a) The hypocalciuric effect of thiazides requires the presence of parathyroid hormone and is not solely a result of sodium depletion. (b) The hypercalcemic effect of thiazides in hypoparathyroidism is due to increased release of calcium from bone and requires the presence of a pharmacologic dose of Vitamin D. (c) Thiazides enhane the action of parathyroid hormone on bone and kidney; Vitamin D can replace parathyroid hormone in this interaction in bone but not in kidney.

This work was presented in part at the Annual Meeting of the Australian Society of Medical Research in Sydney, 1967. (Counc. (G. Brit.) Spec. Rep. Ser. 1967. 2: 138.)

Dr. Parfitt's present address is the Fifth Medical Division, Henry Ford Hospital, Detroit, Mich.

Received for publication 4 November 1971 and in revised form 15 February 1972.

\section{INTRODUCTION}

A fall in urinary calcium excretion is consistently produced by thiazide diuretics and is sustained for as long as the drugs are given (1-4). This fall has been successfully exploited in the treatment of renal stones for over a decade $(5,6)$, but it is still unexplained. Thiazide-induced hypocalciuria is partly reversed by giving sodium chloride, $250 \mathrm{mEq}$ daily (7). Consequently, the hypocalciuria has been attributed to enhanced reabsorption of both sodium and calcium in the proximal convoluted tubule in response to sodium depletion (7); this theory has become widely accepted $(8,9)$.

The effect of thiazide diuretics on plasma calcium is more complex. An initial rise in total calcium is common, but this reflects a rise in total protein and proteinbound calcium due to sodium and water depletion, and is transient (10). The plasma calcium remains normal even after many years in the great majority of patients given a thiazide $(4,6,10,11)$, but in a few it may rise significantly $(10,11)$. This is especially likely in patients with primary hyperparathyroidism (10) and in anephric patients with secondary hyperparathyroidism on maintenance hemodialysis (12). These observations suggested that thiazides might enhance the peripheral actions of parathyroid hormone $(\mathrm{PTH})^{1}$ on kidney and bone $(10,12)$.

Thiazide diuretics also induce parathyroid hyperplasia in dogs (13) and (less certainly) in man (11), but not in rats (14). Hypercalcemia might therefore reflect an increase in PTH secretion, rather than enhancement of the peripheral actions of PTH (which should lead to no change or possibly to parathyroid involution).

${ }^{1}$ Abbreviations used in this paper: IPE, index of phosphate excretion; PTH, parathyroid hormone; SHP, surgical hypoparathyroidism. 
TABLE I

Details of Patients Studied

\begin{tabular}{|c|c|c|c|c|c|c|c|c|c|c|}
\hline \multirow{2}{*}{ Case } & \multirow{2}{*}{ Age } & \multirow{2}{*}{ Sex } & \multirow{2}{*}{ Weight } & \multicolumn{3}{|c|}{ Thiazide } & \multirow{2}{*}{$\mathrm{Ca}^{*}$} & \multirow{2}{*}{ P* } & \multirow{2}{*}{ Cał } & \multirow{2}{*}{$\mathbf{P \ddagger}$} \\
\hline & & & & Drug & Dos & & & & & \\
\hline \multicolumn{11}{|c|}{ Hypoparathyroidism } \\
\hline 1 & 28 & $\mathrm{~F}$ & 52.8 & Methyclothiazide & 20 & $\mathrm{mg}$ & 5.4 & 6.7 & 10.1 & 3.6 \\
\hline 2 & 49 & $\mathrm{~F}$ & 50.8 & " & 20 & “ & 7.0 & 5.5 & 9.9 & 5.2 \\
\hline 3 & 59 & $\mathrm{~F}$ & 58.5 & Chlorothiazide & 2.0 & $\mathrm{~g}$ & 6.3 & 5.6 & 10.5 & 4.5 \\
\hline 4 & 62 & $\mathrm{~F}$ & 57.3 & Methyclothiazide & 20 & $\mathrm{mg}$ & 5.8 & 4.5 & 9.9 & 3.8 \\
\hline 5 & 50 & $\mathrm{~F}$ & 47.3 & " & 20 & “ & 7.2 & 4.1 & 10.3 & 3.2 \\
\hline 6 & 55 & $\mathrm{~F}$ & 56.9 & “ & 20 & “ & 7.1 & 4.4 & 9.5 & 4.6 \\
\hline 7 & 72 & $\mathbf{F}$ & 54.6 & “ & 20 & “ & 5.7 & 4.4 & 10.4 & 4.2 \\
\hline 8 & 53 & $\mathrm{~F}$ & 54.1 & “ & 20 & “ & 6.6 & 4.5 & 9.8 & 3.3 \\
\hline \multicolumn{4}{|c|}{ Hypercalciuria } & & & & \multicolumn{4}{|c|}{ Diagnosis } \\
\hline 9 & 22 & $\mathbf{M}$ & 85.4 & Chlorothiazide & 2.0 & $\mathrm{~g}$ & \multicolumn{4}{|c|}{ Calcium stones-immobilization } \\
\hline 10 & 25 & $\mathrm{~F}$ & 59.0 & Methyclothiazide & 20 & $\mathrm{mg}$ & \multicolumn{4}{|c|}{ Uric acid stones } \\
\hline 11 & 24 & $\mathbf{M}$ & 75.5 & “ & 20 & “" & \multicolumn{4}{|c|}{ Renovascular hypertension } \\
\hline 12 & 41 & $\mathbf{M}$ & 94.5 & “ & 20 & “ & \multicolumn{4}{|c|}{ Calcium stones-idiopathic } \\
\hline 13 & 48 & M & 82.4 & “ & 20 & “ & \multicolumn{4}{|c|}{ Calcium stones-idiopathic } \\
\hline 14 & 55 & F & 60.5 & Chlorothiazide & 2.0 & g & \multicolumn{4}{|c|}{ Osteoporosis - postmenopausal } \\
\hline 15 & 55 & $\mathrm{~F}$ & 61.0 & “ & 2.0 & $\mathrm{~g}$ & \multicolumn{4}{|c|}{ Osteoporosis-immobilization } \\
\hline
\end{tabular}

* Values before start of Vitamin D treatment.

$\ddagger$ Values on Vitamin D before thiazide was given.

In order to test some of these theories, the effect of thiazides was studied in patients with hypoparathyroidism treated with Vitamin D. The results indicate that PTH is necesary for hypocalciuria but not for hypercalcemia to occur with thiazides.

\section{METHODS}

A thiazide diuretic in a dose of 4 tablets daily was given for 7 days to seven patients with chronic post-surgical hypoparathyroidism (SHP) treated with Vitamin $\mathrm{D}^{2}$ and to seven patients with hypercalciuria (more than $300 \mathrm{mg} / 24 \mathrm{hr}$ ) who served as controls. Urine was collected daily from 4 days before until 4 days after the thiazide was given. In addition one patient (case 8) with SHP who had never received Vitamin D was given a thiazide for 4 days after the plasma calcium had been raised by i.v. infusion of calcium. Pertinent details of the patients studied with dose and type of thiazide are listed in Table I; all were normocalcemic at the beginning of the study. In the patients with SHP who were on Vitamin D, hypocalcemia had been documented 7-22 yr after surgery, late enough to exclude significant recovery of parathyroid function during Vitamin $\mathrm{D}$ treatment. Vitamin D was given as opaque gelatin capsules containing an arachis oil solution of the active principle in pure crystalline form with hydroquinone as an antioxidant. Extensive experience has indicated that unexplained or unpredictable changes in plasma calcium do not occur in patients treated with this preparation of Vitamin D (15). The duration of Vitamin D therapy was 4 months in case 7 and 3-6 $\mathrm{yr}$ in the others. At the time of study the patients

2 The term "Vitamin D" refers to all substances which are antirachitic in man. were on Vitamin $\mathrm{D}_{2} 2.5 \mathrm{mg}$ daily (case 5), Vitamin $\mathrm{D}_{3} 2.5$ $\mathrm{mg}$ daily (case 2 ), or dihydrotachysterol $0.5-1.0 \mathrm{mg}$ daily (all other cases). ${ }^{3}$ The three hypercalciuric patients with calcium stones (Table I) have remained normocalcemic for 1-3 yr, but another patient (case 14) became mildly hypercalcemic and had a parathyroid adenoma removed 4 yr later. All hypoparathyroid patients were on $0.2-0.3 \mathrm{mg}$ of thyroxine daily except patient 6 who had a normal protein-bound iodine level and ${ }^{131}$ I uptake. Except in case 8, all patients were ambulant and the patients' usual medications were continued in all cases. The diets were not weighed or analyzed, but the intake of milk was kept constant by volume, and the patients were instructed to record and keep as constant as possible their intake of foods high in calcium and sodium; the variation, estimated by review of these records, did not exceed $\pm 10 \%$. The results of one additional patient were excluded because the coefficient of variation $(\mathrm{sD} /$ mean $\times 100)$ of urine calcium in the pretreatment period exceeded $10 \%$. Analytical methods used have been previously cited or described $(10,16)$; the normal range for total plasma calcium corrected for total protein (10) is $9.5-11.0 \mathrm{mg} / 100 \mathrm{ml}$. Urinary excretion data were calculated both as absolute amounts ( $\mathrm{mg}$ or $\mathrm{mEq}$ ) per unit time and as amounts ( $\mu \mathrm{g}$ or $\mu \mathrm{Eq})$ per $100 \mathrm{ml}$ of creatinine clearance $\left(\mathrm{C}_{\mathrm{Cr}}\right)$. The latter rates are designated with the subscript $\mathrm{E}$ after the chemical symbol (17). The relationships of $\mathrm{Ca}_{\mathrm{E}}$ to plasma $\mathrm{Ca}$ in each subject were compared with the values found for different states of parathyroid function (18) with an appropriate correction for the differences in normal range for plasma

\footnotetext{
${ }^{3}$ There are no differences in plasma and urinary calcium, inorganic phosphate and magnesium, or in urinary hydroxyproline between hypoparathyroid patients controlled on Vitamins $\mathrm{D}_{2}$ or $\mathrm{D}_{3}$ or dihydrotachysterol. (A. M. Parfitt, unpublished data).
} 


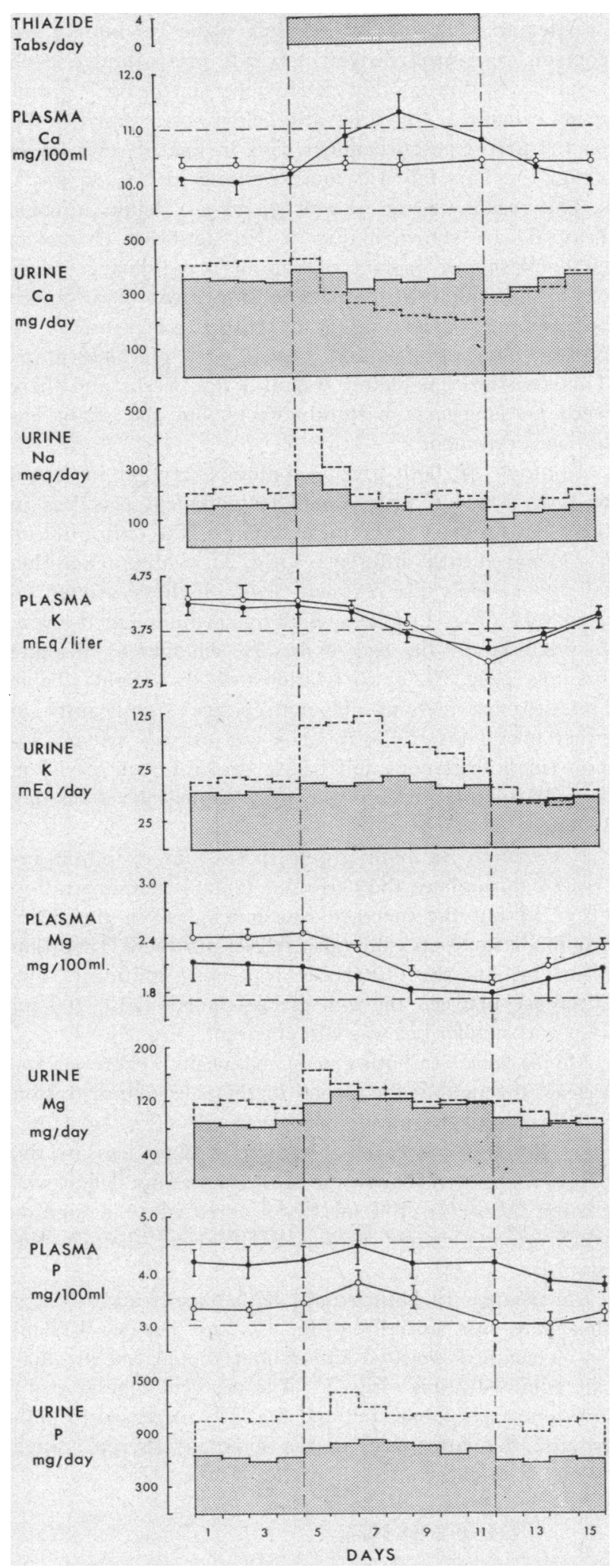

FigURE 1 Effect of a thiazide diuretic on plasma levels and urinary excretion rates (per day) of calcium $(\mathrm{Ca})$, sodium calcium. The index of phosphate excretion (IPE) was calculated from the formula

$$
\mathrm{IPE}=\mathrm{P}_{\mathbf{E}}-\frac{\mathrm{Plasma} \mathrm{P}(\mathrm{mg} / 100 \mathrm{ml})-2.5}{2}
$$

(19). For statistical analysis, group means before and after thiazide were compared using a paired $t$ test and means between groups by an unpaired $t$ test. In addition $95 \%$ and $99 \%$ confidence limits were calculated for each individual from the pooled pretreatment data.

\section{RESULTS}

Calcium. The mean results in the patients with SHP on Vitamin D and in the controls are shown in Figs. 1 and 2 and Tables II and III. In the pretreatment period (days $1-4)$ the coefficient of variation $(\mathrm{sD} /$ mean $\times 100$ ) averaged $4.9 \%$ in the control group and $6.4 \%$ in the SHP group for urine calcium, and $1.1 \%$ in the control group and $1.9 \%$ in the SHP group for plasma calcium. In the control group urine calcium excretion $(\mathrm{mg} / 24 \mathrm{hr}$ ) fell progressively by $44 \%$ from 415 to 232 on day 8 and stayed at approximately this level through day 11 . Plasma total calcium did not change (Fig. 1).

In the SHP group, urine calcium excretion rose slightly from 351 to 387 on days 5 and 6 , fell by $11 \%$ to 311 on day 8 and returned to pretreatment levels by day 11. Neither the initial rise nor the subsequent fall was statistically significant by comparison of group means, but comparison of individual changes with individual confidence limits showed that a significant rise occurred in three of seven subjects on day 5 or 6 , and a significant fall in five of seven subjects on day 7,8 , or 9 . Plasma total calcium $(\mathrm{mg} / 100 \mathrm{ml})$ rose from 10.09 to $10.88,11.29$, and 10.77 at the end of days 6,8 , and 11 , respectively (Fig. 1). A significant rise occurred in each case and in four cases the level rose above the normal range. The differences between the two groups were highly significant both for urine and plasma calcium (Table II). The differences in urine calcium are strikingly shown by the calculation of the cumulative retention of calcium (Fig. 3). The hypercalciuric controls had retained on the average almost $1.5 \mathrm{~g}$ of calcium by the end of the study, whereas the patients with SHP retained only a trivial amount.

Can $(\mu \mathrm{g} / 100 \mathrm{ml} \mathrm{Cor})$ was initially higher in the SHP group than in the controls (Fig. 2), and when the thiazide was given $\mathrm{Ca}_{\mathrm{z}}$ rose in the SHP group but fell in the

$(\mathrm{Na})$, potassium $(\mathrm{K})$, magnesium $(\mathrm{Mg})$, and inorganic phosphate (P). Data from seven hypoparathyroid patients on Vitamin D (plasma, closed circles; urine, solid lines with hatching) and seven hypercalciuric controls (plasma, open circles; urine, dotted lines with no hatching). Horizontal dotted lines enclose normal ranges. Vertical solid lines indicate SEM. 4 tablets contain $20 \mathrm{mg}$ of methyclothiazide or 2.0 $\mathbf{g}$ of chlorothiazide, quantities which are equal in natriuretic potency. 


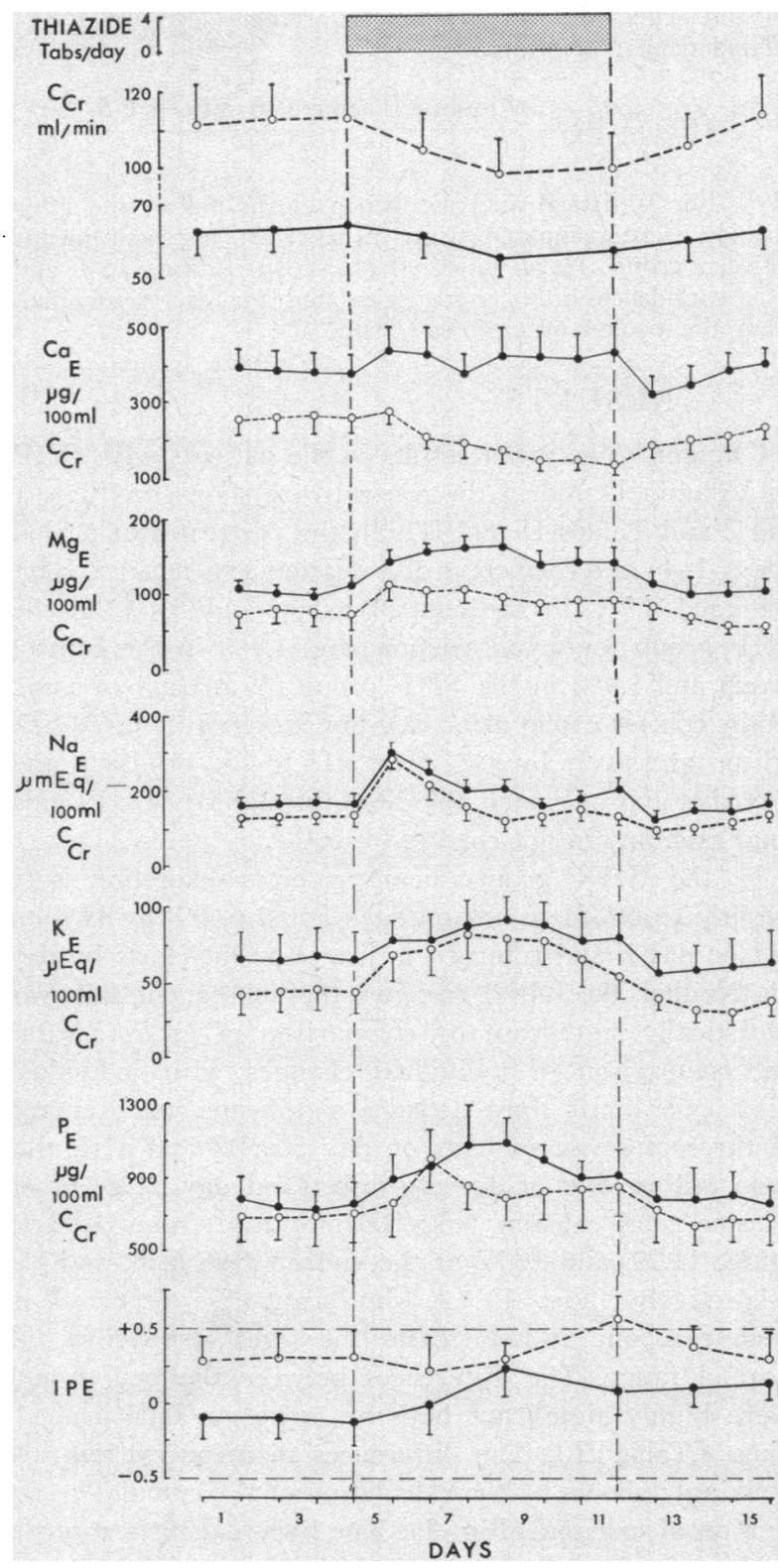

FIGURE 2 Effect of a thiazide diuretic on creatinine clearance $\left(\mathrm{C}_{\mathbf{c r}_{\mathbf{r}}}\right.$ ) urinary excretion rates (per $100 \mathrm{ml} \mathrm{C}_{\mathbf{c r}}$ ) of calcium $\left(\mathrm{Ca}_{\mathrm{E}}\right)$, magnesium $\left(\mathrm{Mg}_{\mathrm{E}}\right)$, sodium $\left(\mathrm{Na}_{\mathrm{E}}\right)$, potassium $\left(\mathrm{K}_{\mathrm{E}}\right)$, and inorganic phosphate $\left(\mathrm{P}_{\mathrm{E}}\right)$, and index of phosphate excretion (IPE). Data from seven hypoparathyroid patients on Vitamin D (closed circles, solid lines) and seven hypercalciuric controls (open circles, dotted lines). Horizontal dotted lines enclose normal ranges. Vertical solid lines indicate SEM.

controls (Table III). In Fig. 4 the changes in Cав plotted against plasma $\mathrm{Ca}$ indicate a shift from the "hypoparathyroid" into the "normal" range in five of seven patients with SHP and a shift from the normal to the hyperparathyroid range in six of seven hypercalciuric controls.
After the thiazide was ceased, urine calcium in the controls rose progressively towards pretreatment levels from day 12 through day 15 . However, in the SHP group, urine calcium fell significantly below pretreatment levels on the first 2 post-treatment days in five of seven cases (Fig. 1). This fall was more striking in $\mathrm{Cam}_{\text {(Fig. 2). }}$

The results in the patient given a calcium infusion (case 9) are shown in Fig. 5. No signficant change in either plasma or urinary calcium occurred during 4 days of thiazide administration. The study was discontinued because of local irritation at the site of infusion; an $\mathrm{X}$-ray of the arm showed a small area of calcification. This resorbed completely within a few weeks and there were no long-term harmful effects, but the study has not been repeated.

Sodium. In both groups sodium excretion increased on days 5 and 6 (Fig. 1). The increment was less in the SHP group, but the increments in $\mathrm{Nax}(\mu \mathrm{Eq} / 100 \mathrm{ml}$

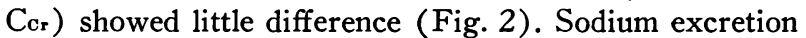
fell to or below pretreatment levels in both groups on days 8-11 (Fig. 1). The cumulative sodium deficits were very similar by the end of day 11 , whether as absolute amounts (Fig. 3), or in relation to body weight (Table IV). Plasma sodium did not change significantly in either group. After the thiazide was ceased, urinary sodium in both groups fell below pretreatment levels on days 12-14 and reached the pretreatment level on day 15 (Fig. 1).

Potassium. In both groups potassium excretion increased throughout the period of thiazide administration (Fig. 1) but the increase was much less in the SHP group. Plasma potassium also fell less in the SHP group (Fig. 1), but this difference was not significant. The difference between the two groups in $\mathrm{K}_{\mathrm{m}}(\mu \mathrm{Eq} / 100 \mathrm{ml}$ $\mathrm{C}_{\mathbf{c r}}$ ) was smaller but was still apparent (Fig. 2).

Magnesium. In both groups magnesium excretion increased throughout the period of thiazide administration and plasma magnesium fell progressively (Fig. 1). However, the fall in plasma magnesium was less in the SHP group, even though the total magnesium deficit was greater. $\mathrm{Mg}_{\mathrm{E}}(\mu \mathrm{g} / 100 \mathrm{ml} \mathrm{Cor})$ increased to a significantly greater extent in the SHP group than in the controls.

Phosphate. In both groups both plasma and urinary phosphate rose initially (Fig. 1), and $\mathrm{P}_{\mathrm{E}}(\mu \mathrm{g} / 100 \mathrm{ml}$ $\mathrm{C}_{\mathrm{cr}}$ ) remained elevated throughout the period of thiazide administration (Fig. 2). The per cent tubular reabsorption of phosphate fell and the IPE increased in both groups; the latter was in the hyperparathyroid range by day 7 in the controls (Fig. 2, Table III).

\section{DISCUSSION}

The effect of a thiazide diuretic on urinary calcium in the patients with SHP differed from the effect in a 


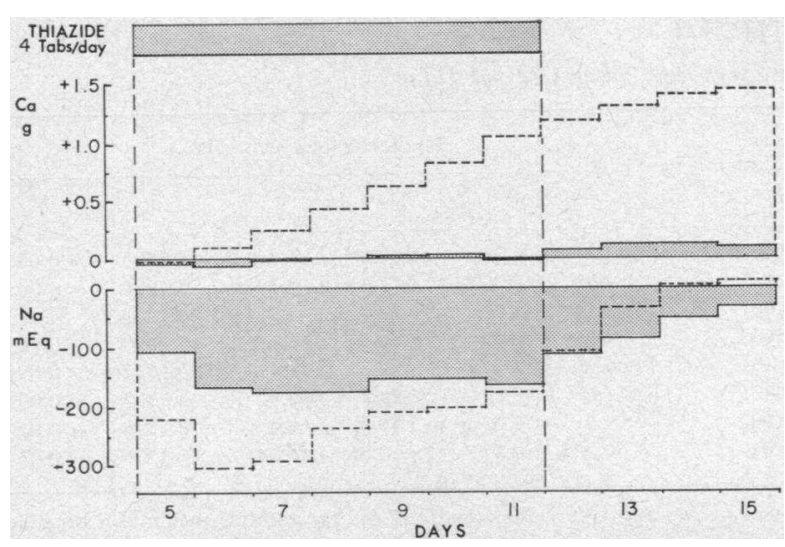

Figure 3 Cumulative changes in urinary retention of calcium and deficit of sodium in seven hypoparathyroid patients on Vitamin D (solid lines with hatching) and seven hypercalciuric controls (dotted lines with no hatching).

control group in three respects. Firstly, the maximum fall was much less- $11 \%$ compared to $44 \%$; secondly, this effect was not sustained; and thirdly, the urine calcium changed in opposite directions in the two groups after the thiazide was ceased. Although these results, which agree with those of other workers (20), strongly suggest that PTH is necessary for the usual hypocalciuric effect of thiazides, the possible significance of other differences between the two groups must first be examined.

Because of the nature of their diseases, the age and sex composition of the two groups necessarily differed, but neither age nor sex affect the hypocalciuric response to thiazides $(1-6)$, and these differences may be disregarded except for their effect on body weight. Expressed

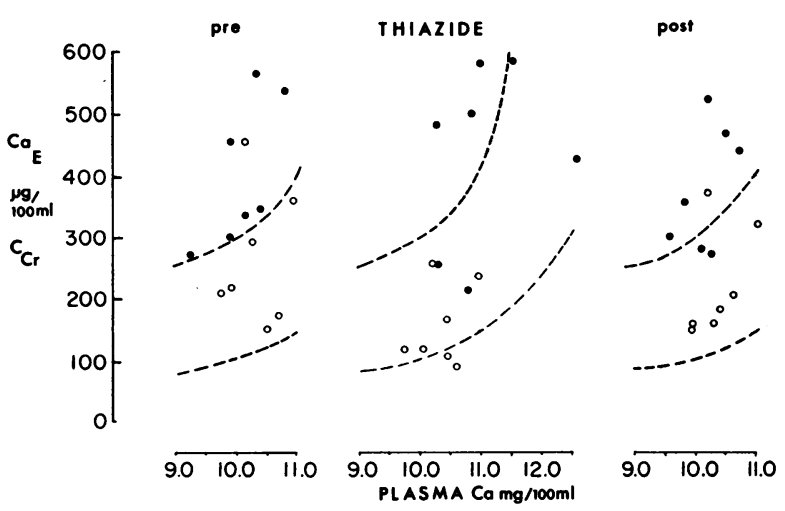

Figure 4 Relationship between plasma $\mathrm{Ca}$ and $\mathrm{Ca}$ in seven hypoparathyroid patients on Vitamin D (closed circles) and seven hypercalciuric controls (open circles). Each point represents the mean of two to three values in a single patient before (pre) during or after (post) thiazide administration. Curved dotted lines enclose normal range (18), adjusted for difference in normal range for plasma Ca. Area above and to the left of the normal range corresponds to reduced tubular reabsorption of calcium ("hypoparathyroid"), and area below and to the right of the normal range corresponds to increased tubular reabsorption ("hyperparathyroid").

in relation to body weight the magnitude of the initial sodium deficit was smaller in the patients with SHP (Table IV). This difference was probably a consequence of the lower creatinine clearance in these patients (Fig. 2) rather than of a difference in the tubular response to the diuretic. The natriuretic potency of thiazides is impaired in subjects with reduced glomerular filtration rate (21), but the increment in sodium excretion per unit of filtered load is usually unchanged (22). None of the SHP patients had been intoxicated with Vitamin D, but

TABLE II

Effect of a Thiazide Diuretic on Plasma and Urinary Electrolytes (Original Data)

\begin{tabular}{|c|c|c|c|c|c|c|c|c|}
\hline & & SHP on Vitamin I & & & & Hypercalciuric contr & & \\
\hline & Control & Test & $t$ & $P$ & Control & Test & $t$ & $P$ \\
\hline Plasma & & & & & & & & \\
\hline $\mathrm{Ca}(m g / 100 m l)$ & $10.09 \pm 0.11$ & $10.93 \pm 0.16$ & 4.6856 & $<0.001$ & $10.32 \pm 0.09$ & $10.36 \pm 0.08$ & 0.6832 & n.s. \\
\hline $\mathrm{P}(m g / 100 m l)$ & $4.14 \pm 0.25$ & $4.47 \pm 0.30$ & 1.8172 & $<0.10$ & $3.24 \pm 0.07$ & $3.67 \pm 0.16$ & 2.8400 & $<0.01$ \\
\hline $\mathrm{Mg}(\mathrm{mg} / 100 \mathrm{ml})$ & $1.09 \pm 0.13$ & $1.84 \pm 0.09$ & 2.8283 & $<0.02$ & $2.40 \pm 0.06$ & $2.03 \pm 0.07$ & 4.4572 & $<0.001$ \\
\hline $\mathrm{K}(m E q /$ liter $)$ & $4.22 \pm 0.10$ & $3.71 \pm 0.12$ & 4.6177 & $<0.001$ & $4.31 \pm 0.13$ & $2.71 \pm 0.15$ & 4.7874 & $<0.001$ \\
\hline $24 \mathrm{hr}$ urine & & & & & & & & \\
\hline Ca (mg, days 8-11) & $351.1 \pm 25.5$ & $348.4 \pm 27.4$ & 0.2485 & n.s. & $410.5 \pm 22.6$ & $212.5 \pm 14.6$ & 14.5671 & $<0.001$ \\
\hline $\mathrm{Na}(m E q$, days 8-11) & $143.5 \pm 8.9$ & $141.0 \pm 7.5$ & 0.2792 & n.s. & $210.4 \pm 14.5$ & $172.3 \pm 14.1$ & 2.4586 & $<0.025$ \\
\hline $\mathrm{P}(m g$, days $5-8)$ & $617.9 \pm 21.3$ & $779.3 \pm 23.6$ & 5.6282 & $<0.001$ & $1052.0 \pm 79.0$ & $1170.0 \pm 76.0$ & 2.6444 & $<0.02$ \\
\hline $\mathrm{Mg}(m g$, days $5-8)$ & $87.8 \pm 4.5$ & $122.8 \pm 6.4$ & 7.9724 & $<0.001$ & $114.2 \pm 8.3$ & $142.9 \pm 10.0$ & 3.2232 & $<0.005$ \\
\hline $\mathrm{K}(m E q$, days $5-8)$ & $51.0 \pm 3.5$ & $60.2 \pm 2.6$ & 3.1652 & $<0.005$ & $63.4 \pm 4.5$ & $111.2 \pm 9.0$ & 6.1822 & $<0.001$ \\
\hline
\end{tabular}

Each figure for plasma is mean $\pm \mathrm{SE}$ of three values in each subject. Each figure for $24 \mathrm{hr}$ urine is mean $\pm \mathrm{SE}$ of four values in each subject. Control values obtained before and test values obtained during administration of a thiazide diuretic 4 tablets daily for 7 days. SHP = surgical hypoparathyroidism; n.s. = not significant. 
TABLE III

Effect of a Thiazide Diuretic on Clearances and Other Derived Data

\begin{tabular}{|c|c|c|c|c|c|c|c|c|c|c|}
\hline \multirow{3}{*}{$\frac{\text { Variable }}{C_{C r}(m l / m i n)}$} & \multicolumn{4}{|c|}{ SHP on Vitamin D } & \multicolumn{6}{|c|}{ Hypercalciuric controls } \\
\hline & Control & Test & \multirow{2}{*}{$\frac{t}{3.9377}$} & \multirow{2}{*}{$\frac{P}{<0.001}$} & \multicolumn{2}{|c|}{ Control } & \multicolumn{2}{|c|}{ Test } & \multirow{2}{*}{$\frac{t}{7.3605}$} & \multirow{2}{*}{$\frac{P}{<0.001}$} \\
\hline & $63.4 \pm 3.5$ & $57.8 \pm 3.0$ & & & 112.4 & \pm 5.3 & 100.6 & \pm 5.2 & & \\
\hline $\mathrm{C}_{\mathrm{Ca}}(\mathrm{ml} / \mathrm{min})$ & $4.01 \pm 0.32$ & $3.68 \pm 0.29$ & 1.8991 & $<0.10$ & 4.62 & \pm 0.30 & 2.63 & \pm 0.19 & 8.4926 & $<0.001$ \\
\hline $\mathrm{C}_{\mathrm{P}}(\mathrm{ml} / \mathrm{min})$ & $10.5 \pm 0.4$ & $12.5 \pm 0.6$ & 3.9755 & $<0.001$ & 22.5 & \pm 1.9 & 23.7 & \pm 2.0 & 1.1474 & n.s. \\
\hline $\mathrm{C}_{\mathrm{Mg}_{\mathrm{g}}}(\mathrm{ml} / \mathrm{min})$ & $3.90 \pm 0.38$ & $5.76 \pm 0.37$ & 8.7608 & $<0.001$ & 4.63 & \pm 0.44 & 6.04 & \pm 0.38 & 3.9829 & $<0.001$ \\
\hline CaE $\left(\mu g / 100 \mathrm{ml} \mathrm{C} \mathrm{Cr}_{r}\right)$ & $399.8 \pm 24.8$ & $440.9 \pm 33.0$ & 1.7849 & $<0.10$ & 266.7 & \pm 22.9 & 172.3 & \pm 16.7 & 6.9352 & $<0.001$ \\
\hline $\operatorname{Pe}\left(\mu \mathrm{g} / 100 \mathrm{ml} \mathrm{C} \mathrm{Cr}_{r}\right)$ & \pm 54.7 & \pm 72.1 & 6.1483 & $<0.001$ & 671.5 & \pm 82.0 & 829.8 & \pm 92.9 & 5.1338 & $<0.001$ \\
\hline Per cent TRP & $82.3 \pm 1.4$ & $76.6 \pm 1.4$ & 4.8902 & $<0.001$ & 79.2 & \pm 2.6 & 76.3 & \pm 2.4 & 2.7548 & $<0.02$ \\
\hline IPE & $-0.102 \pm 0.86$ & $0.099 \pm 0.112$ & 3.0597 & $<0.01$ & 0.295 & $5 \pm 0.191$ & 0.56 & $5 \pm 0.141$ & 2.1576 & $<0.05$ \\
\hline
\end{tabular}

Each figure is mean \pm SE of three values in each subject. Control values obtained before and test values obtained during administration of a thiazide diuretic 4 tablets daily for 7 days. SHP = surgical hypoparathyroidism; per cent TRP = tubular reabsorption of phosphate as per cent of filtered load; IPE $=$ index of phosphate excretion (see text); n.s., not significant.

impaired renal function may occur with Vitamin D treatment even in the absence of documented hypercalcemia (A. M. Parfitt, unpublished data).

Sodium depletion may induce hypocalciuria (23), and has been suggested as the explanation for the hypocalciuria effect of thiazides (7). Sodium excretion in the control group was significantly below pretreatment level on days 8-11 (Table II) whereas in the SHP group both sodium and calcium excretion had returned to pretreatment levels on these days. Also, in the control group, but not in the SHP group, the magnitude of the initial sodium deficit (but not the cumulative deficit) correlated significantly with the subsequent percentage fall in urine calcium (Table IV). However, four of the SHP group lost as much sodium on days 5 and 6 as any in the control group, but did not develop sustained hypocalciuria. A significant fall in urine calcium occurred in 5 of the 7 SHP patients on the first day (7, 8 , or 9 ) on which urine sodium fell below control levels; urine calcium subsequently returned to the base line level in each case regardless of whether sodium excretion fell further, rose or remained unchanged. Also, the fall in sodium excretion which occurred after cessation of the diuretic was associated in four of the seven SHP cases with a fall in urine calcium to a lower level than occurred during thiazide administration. A transient fall in urine calcium at a time of sodium retention thus occurred in every case of SHP either during or after cessation of thiazide. These observations suggest that the difference in the degree of sodium depletion (which was in any case not statistically significant) does not explain the difference in calcium excretion between the two groups, and furthermore that sodium depletion is not the whole cause of sustained hypocalciuria with thiazides.

Correction of potassium depletion in one thiazidetreated patient caused a slight rise in urinary calcium (4), but the hypocalciuric effect remained much greater than in the presently reported patients with SHP. It is therefore unlikely that the difference in the extent of potassium depletion between the two groups accounts for the difference in calcium excretion. The differences in magnesium and phosphate between the two groups were small and except for the plasma magnesium were statistically insignificant. Finally, Vitamin D does not inhibit the hypocalciuric effect of thiazides when given for treatment of conditions other than hypoparathyroidism (10), so that treatment with Vitamin D would not explain the absence of hypocalciuria in the patients with SHP.

It seems reasonable to conclude that deficiency of PTH was mainly responsible for the lack of sustained hypocalciuria in the SHP patients. This deficiency may not have been complete, since in most patients with SHP it is likely that approximately $5-15 \%$ of parathyroid cell mass is preserved (24). It is apparent, however, that the sustained fall in urine calcium of $40-50 \%$ which usually occurs with thiazides requires the presence of at least normal levels of PTH.

If the tubular reabsorption of calcium did not change at all in the SHP patients, why did not urine calcium excretion rise in response to the hypercalcemia? In part this was prevented by the fall in $\mathrm{C}_{\mathrm{Cr}}$ (Fig. 2), and $\mathrm{Cam}\left(\mu \mathrm{g} / 100 \mathrm{ml} \mathrm{C} \mathrm{Cr}_{\mathrm{r}}\right)$ did rise in the SHP patients (Fig. 3). However, the relationship between $\mathrm{Cax}$ and plasma $\mathrm{Ca}$ changed in a manner which indicated a small increase in calcium reabsorption (Fig. 4). This may have resulted from a small residue of parathyroid function, or more likely, from sodium depletion or some other PTH-independent effect of thiazides.

There are many resemblances between the renal effects of PTH and thiazides (25). Like the thiazides, PTH increases sodium, water, potassium, bicarbonate, and phosphate excretion acutely (25-27). Both thiazides (3) and PTH (18) cause increased tubular reabsorption of calcium chronically. However, unlike the 
TABLE IV

Sodium Deficits and Changes in Urinary Calcium in Individual Cases

\begin{tabular}{|c|c|c|c|c|c|c|}
\hline \multirow[b]{2}{*}{ Case } & \multicolumn{2}{|c|}{ Sodium deficit } & \multicolumn{4}{|c|}{ Urine calcium } \\
\hline & $\begin{array}{c}\text { Initial } \\
\text { (days 5-6) }\end{array}$ & $\begin{array}{c}\text { Total } \\
\text { (days 5-11) }\end{array}$ & $\begin{array}{c}\text { Max. fall } \\
\text { (days 7-9) }\end{array}$ & $\begin{array}{r}\text { Max. fall } \\
\text { (days 7-9) }\end{array}$ & $\begin{array}{l}\text { Sust. fall } \\
\text { (day 11) }\end{array}$ & $\begin{array}{l}\text { Sust. fall } \\
\text { (day 11) }\end{array}$ \\
\hline & $m E q / k g$ & $m E q / k g$ & $m g / d a y$ & $\%$ & $m g / d a y$ & $\%$ \\
\hline \multicolumn{7}{|c|}{ Hypoparathyroid } \\
\hline 1 & 3.68 & 5.51 & 21 & 6.4 & -100 & -30.7 \\
\hline 2 & 5.89 & 6.46 & 71 & 30.4 & 7 & 3.0 \\
\hline 3 & 2.32 & 6.10 & 113 & 21.2 & -46 & -8.6 \\
\hline 4 & 1.68 & 0.45 & 152 & 31.1 & 10 & 2.1 \\
\hline 5 & 6.64 & 8.25 & 116 & 25.4 & -36 & -7.9 \\
\hline 6 & 1.93 & -3.55 & 103 & 41.5 & 18 & 7.3 \\
\hline 7 & 1.02 & -0.42 & -20 & -11.6 & -58 & -33.7 \\
\hline Mean & $3.309 \pm 0.826$ & $3.255 \pm 1.662$ & $79.4 \pm 22.7$ & $20.6 \pm 6.7$ & $-29.3 \pm 16.4$ & $-9.8 \pm 6.2$ \\
\hline \multicolumn{7}{|c|}{ Hypercalciuric controls } \\
\hline 9 & 2.36 & -0.03 & 340 & 54.8 & 304 & 49.0 \\
\hline 10 & 8.94 & 10.66 & 197 & 63.5 & 231 & 74.5 \\
\hline 11 & 3.52 & 0.72 & 152 & 55.5 & 121 & 44.4 \\
\hline 12 & 2.51 & -2.06 & 218 & 51.6 & 201 & 47.6 \\
\hline 13 & 4.67 & 0.87 & 210 & 42.4 & 308 & 62.0 \\
\hline 14 & 3.98 & 6.03 & 232 & 51.2 & 148 & 32.7 \\
\hline 15 & 5.12 & 5.67 & 161 & 53.0 & 174 & 57.1 \\
\hline Mean & $4.443 \pm 0.843$ & $3.123 \pm 1.686$ & $215.7 \pm 23.5$ & $53.1 \pm 2.4$ & $212.4 \pm 27.6$ & $52.5 \pm 5.1$ \\
\hline$t$ & 0.9608 & 0.0555 & 4.1724 & 4.5528 & 7.5344 & 7.7648 \\
\hline$P$ & n.s. & n.s. & $<0.01$ & $<0.005$ & $<0.001$ & $<0.001$ \\
\hline \multirow[t]{2}{*}{$\mathrm{r}(\mathrm{SHP})$} & \multicolumn{2}{|c|}{ Initial $\mathrm{Na}$ deficit } & 0.155 & 0.270 & -0.003 & 0.196 \\
\hline & \multicolumn{2}{|c|}{ Total $\mathrm{Na}$ deficit } & 0.076 & -0.060 & -0.394 & -0.127 \\
\hline \multirow[t]{2}{*}{ r (control) } & \multicolumn{2}{|c|}{ Initial $\mathrm{Na}$ deficit } & -0.402 & 0.503 & 0.025 & $0.763^{*}$ \\
\hline & \multicolumn{2}{|c|}{ Total Na deficit } & 0.283 & -0.555 & -0.189 & 0.428 \\
\hline \multirow[t]{2}{*}{ r (both group } & \multicolumn{2}{|c|}{ Initial $\mathrm{Na}$ deficit } & 0.125 & 0.387 & 0.249 & 0.422 \\
\hline & \multicolumn{2}{|c|}{ Total $\mathrm{Na}$ deficit } & 0.081 & 0.042 & -0.122 & 0.036 \\
\hline
\end{tabular}

$t$ and $P$ values refer to differences between cases $1-7$ and cases $10-16$ in each column. $r$ values are productmoment correlation coefficients of quantity indicated at head of column (as dependent variable) with quantity indicated on the left (as independent variable).

* Correlation coefficient, $P<0.05 ;$ n.s., not significant.

thiazides PTH decreases magnesium excretion (28). The thiazides are thought to act on the cortical-diluting segment of the nephron (29). The site of action of $\mathrm{PTH}$ on calcium reabsorption is unknown, but stopflow (30), microperfusion (31), and clearance (32) studies suggest the distal rather than the proximal nephron. The available data are thus consistent with the theory that the thiazides and PTH have a common site of action in the nephron, possibly the corticaldiluting segment. The absence of hypercalcemia and the persistence of increased urinary magnesium, both in the present control subjects and in most patients with idiopathic hypercalciuria suggest that the calcium-conserving effect of the thiazides is dependent on some interaction with PTH on the nephron, rather than to increased secretion of PTH.
The resistance of the SHP patients to hypocalciuria with thiazides is in striking contrast to their susceptibility to hypercalcemia. This susceptibility must depend in some way on Vitamin D treatment since thiazides have no significant effect on calcium metabolism in the absence both of PTH and of a pharmacologic dose of Vitamin D, whether in completely untreated patients (33) or when normocalcemia is induced by calcium infusion (Fig. 5). The extra calcium which appeared in the blood of the SHP patients could not have come from increased renal tubular reabsorption from the urine (Fig. 3). Although radiocalcium absorption may be increased in the first few days (34), fecal calcium excretion is unchanged within the first 2 wk of thiazide treatment (35) and after several months radiocalcium absorption is depressed (36) and fecal calcium is 


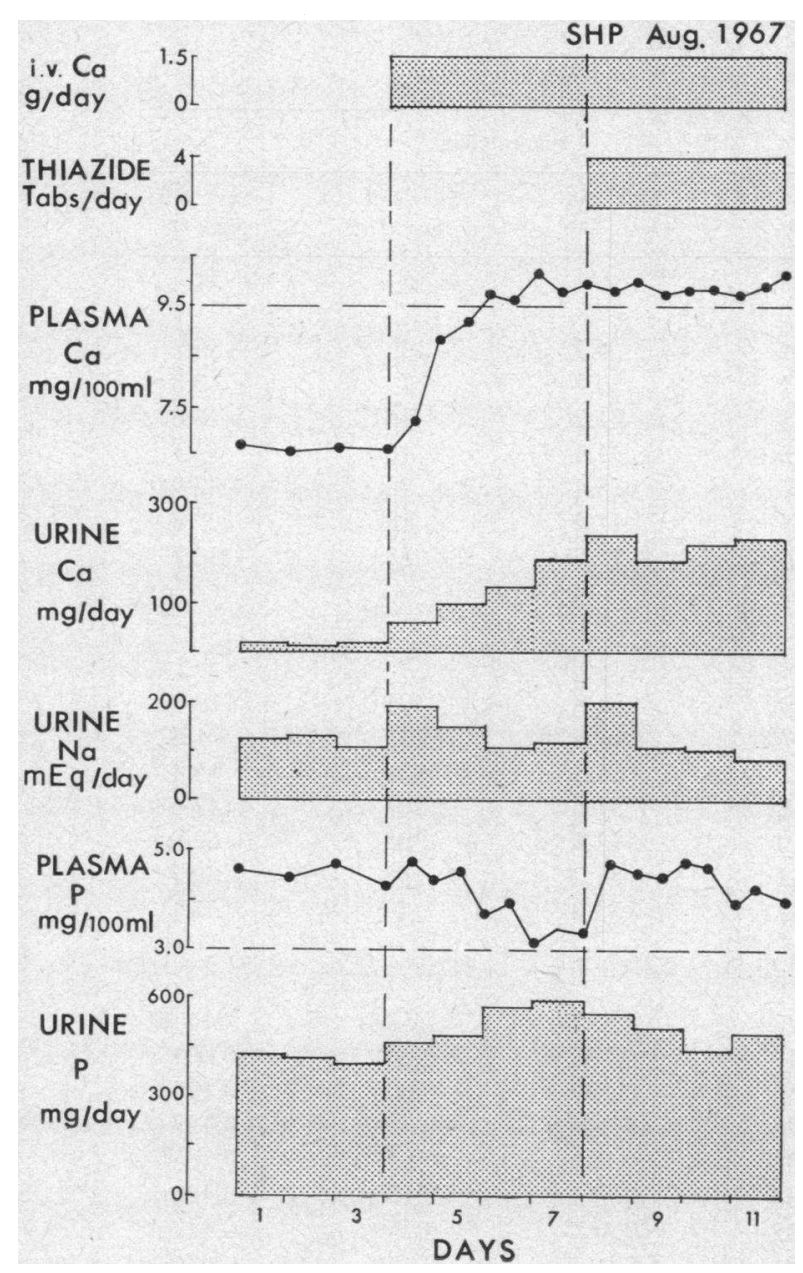

FiguRE 5 Effect of a thiazide diuretic on plasma and urinary calcium $(\mathrm{Ca})$ and inorganic phosphate $(P)$ and urinary sodium $(\mathrm{Na})$ in a patient with surgical hypoparathyroidism rendered normocalcemic by continuous i.v. infusion of calcium.

increased (37). Although an increase in calcium absorption has not been directly excluded in the present studies, it seems an unlikely explanation for the hypercalcemia. By exclusion, bone seems the probable source of the additional calcium. An effect on bone also explains the rise in plasma phosphate which occurred in both SHP patients and controls, and the rise in plasma magnesium as well as calcium in anephric patients in response to thiazide administration (12).

It has been suggested that an initial high rate of bone resorption is a major determinant of thiazide-induced hypercalcemia (38). If bone formation is not similarly increased and calcium balance is strongly negative, maintenance of a normal or only slightly raised plasma calcium may be critically dependent on a high rate of urinary calcium excretion, and so is readily compromised by thiazide-induced hypocalciuria' (10, 18). This is probably the explanation for the adverse effect of thiazides in myelomatosis and secondary neoplasia of bone (39). However, the response to thiazides bears no simple relation to bone resorption when formation and resorption rates are closely matched and calcium balance is zero or only slightly negative. This is so in idiopathic hypercalciuria (40), in primary hyperparathyroidism (41), and in Vitamin D-treated hypoparathyroidism (42). Of these three conditions, bone resorption is increased in the first two $(40,41)$ but not in the third (42), whereas thiazide-induced hypercalcemia occurs in the last two (reference and $10 \mathrm{Fig}$. 1) but not in the first (3-6). The data suggest that thiazides cause increased release of calcium from bone by some mechanism unrelated to the prevailing rate of bone resorption, but only in the presence of abnormally high levels of either PTH or Vitamin D.

Thiazides thus interact with PTH to potentiate its effects on both bone and kidney, but a high dose of Vitamin D can replace PTH in this interaction in bone but not in kidney, which is in keeping with PTHVitamin D interactions in other circumstances (43). This accounts for all the findings with the exception of early hypersecretion of PTH in normal subjects (44) and long-term parathyroid hyperplasia $(11,13)$. Both of these abnormalities could result from magnesium depletion (45), which is an early and consistent effect of thiazide administration.

The absence of thiazide-induced hypercalcemia in idiopathic hypercalciuria reflects primarily the absence of the thiazide effect on bone with normal levels of PTH and Vitamin D. However it is still pertinent to consider why the renal retention of large amounts of calcium (around $70 \mathrm{~g}$ per year) does not regularly induce hypercalcemia, especially in view of the recent suggestion that the renal tubular reabsorption of calcium is a major determinant of steady-state plasma calcium levels (18). Since neither increased bone density nor soft tissue calcification are observed even after many years (6), most of the retained calcium must eventually be lost by some other route, presumably fecal excretion $(36,37)$. Any short-term accumulation of calcium is probably taken up by bone (34). The mechanism of these short- and long-term adjustments is obscure, but they would be facilitated by a fall in plasma PTH; this occurs in most patients with idiopathic hypercalciuria given a thiazide (46), but not in normal subjects (44) in whom an early rise is followed by a return to normal levels.

The multiple effects of thiazides in different circumstances may now be summarized. With an excessive amount of PTH, thiazides increase calcium reabsorption by the renal tubule (10), and increase calcium 
release from bone $(10,11)$. With normal amounts of PTH and Vitamin D, thiazides increase calcium reabsorption but not calcium release from bone (3-6). With a reduced amount or absence of PTH but an excessive amount of Vitamin D, thiazides do not directly alter calcium reabsorption, but increase calcium release from bone (Fig. 1). Finally, with no PTH or Vitamin $\mathrm{D}$, thiazides do not alter calcium reabsorption or calcium release from bone.

\section{ACKNOWLEDGMENTS}

The author thanks Mrs. C. Cornish, Mr. T. French, Mr. R. McDowell, Miss D. Keating, Mrs. V. Cartwright, and Mrs. J. Kellner who gave (at different times) valuable technical assistance, Drs. B. Blanckenburg, L. E. Hughes, B. R. Knowles, A. Knyvett, H. M. Lloyd, L. Maguire, C. Mann, J. Phillips, B. S. Rudolph, and J. De Vidas who referred patients, and Mr. C. MacBain who drew the figures.

The work was supported by grants from Merck, Sharp and Dohme (Australia) and the National Health and Medical Research Council of Australia.

\section{REFERENCES}

1. Lichtwitz, A., R. Parlier, D. Hioco, Ch. Prouzet, L. F. Miravet, and S. deSeze. 1960. L'hypocalciurie de l'hydroflumethiazide. Pathol. Biol. 8: 1873.

2. Lichtwitz, A., R. Parlier, S. deSeze, D. Hioco, and L. Miravet. 1961. L'effet hypocalciurique des sulfamides diuretiques. Sem. Hop. $37: 2350$.

3. Higgins, B. A., J. R. Nassim, J. Collins, and A. Hilb. 1964. The effect of bendrofluazide on urine calcium excretion. Clin. Sci. (London). 27: 457.

4. Yendt, E. R., R. J. A. Gagné, and M. Cohanim. 1966. The effects of thiazides in idiopathic hypercalciuria. Amer. J. Med. Sci. 251: 449.

5. Nassim, J. R., and B. A. Higgins. 1965. Control of idiopathic hypercalciuria. Brit. Med. J. 1: 675 .

6. Yendt, E. R., G. F. Guay, and D. A. Garcia. 1970. The use of thiazides in the prevention of renal calculi. Can. Med. Ass. J. 102 : 614.

7. Suki, W. N., A. R. Hull, F. C. Rector, and D. W. Seldin. 1967. Mechanism of the effect of thiazide diuretics on calcium and uric acid. Clin. Res. 15: 78.

8. Epstein, F. H. 1968. Calcium and the kidney. Amer. J. Med. $45: 700$.

9. Anderton, J. L., and P. Kincaid-Smith. 1970. Diuretics: Physiological and Pharmacological Considerations. New Ethicals. May, 81.

10. Parfitt, A. M. 1969. Chlorothiazide induced hypercalcemia in juvenile osteoporosis and primary hyperparathyroidism. N. Engl. J. Med. 281: 55.

11. Paloyan, E., M. Forland, and J. R. Pickleman. 1969. Hyperparathyroidism co-existing with hypertension and prolonged thiazide administration. J. Amer. Med. Ass. 210: 1243 .

12. Koppel, M. H., S. G. Massry, J. R. Shinaburger, D. L. Hartenbower, and J. W. Coburn. 1970. Thiazide induced rise in serum calcium and magnesium in patients on maintenance hemodialysis. Ann. Intern. Med. 72: 895.

13. Pickleman, J. R., F. H. Straus, M. Forland, and E. Paloyan. 1969. Thiazide induced parathyroid stimulation. Metab. (Clin. Exp.). 18: 867.
14. Hahn, T. J., and L. V. Avioli. 1970. Effects of parenteral thiazide administration on parathyroid function. Clin. Res. 18: 31 .

15. Parfitt, A. M. 1970. Vitamin D treatment in hypoparathyroidism. Lancet. $2: 614$.

16. Parfitt, A. M. 1969. The study of parathyroid function in man by EDTA infusion. J. Clin. Endocrinol. Metab. 29: 569 .

17. Nordin, B. E. C., A. Hodgkinson, and M. Peacock. 1967. The measurement and meaning of urinary calcium. Clin. Orthop. Related Res. 52: 293.

18. Nordin, B. E. C., and M. Peacock. 1969. The role of the kidney in regulation of plasma calcium. Lancet. 28: 1280.

19. Nordin, B. E. C., and L. Bulusu. 1968. A modified index of phosphate excretion. Postgrad. Med. J. 44: 93.

20. Brickman, A. S., J. W. Coburn, M. H. Koppel, and S. G. Massry. 1971. Studies on the mechanism of thiazide induced hypocalciuria in man. Clin. Res. 19: 194.

21. Schreiner, G. E., and H. A. Bloomer. 1957. Effect of chlorothiazide on the edema of cirrhosis, nephrosis, congestive heart failure and chronic renal insufficiency. N. Engl. J. Med. 257: 1016.

22. Kleeman, C. R., R. Okun, and R. J. Heller. 1966. The renal regulation of sodium and potassium in patients with chronic renal failure, and the effect of diuretics on the excretion of these ions. Ann. N.Y.Acad. Sci. 139.2: 520 .

23. Kleeman C. R., J. Bohannan, D. Bernstein, S. Ling, and M. H. Maxwell. 1964. Effect of variations in sodium intake on calcium excretion in normal humans. Proc. Soc. Exp. Biol. Med. 115: 29.

24. Parfitt, A. M. 1972. The spectrum of hypoparathyroidism. J. Clin. Endocrinol. Metab. 34: 152.

25. Nordin, B. E. C. 1960 . The effect of intravenous parathyroid extract on urinary $\mathrm{pH}$, bicarbonate and electrolyte excretion. Clin. Sci. (London). 19: 311.

26. Gershberg, H., D. R. Shields, and S. R. Kove. 1959. The acute effects of parathyroid extract in states of edema, diminished renal function and parathyroid disease. J. Clin. Endocrinol Metab. 19: 681.

27. Hellman, D. E., W. Y. W. Au, and F. C. Bartter. 1965. Evidence for a direct effect of parathyroid hormone on urinary acidification. Amer. J. Physiol. 209: 643.

28. Shelp, W. D., T. H. Steele, and R. E. Reiselbach. 1969. Comparison of urinary phosphate, urate and magnesium excretion following parathyroid hormone administration to normal man. Metab. (Clin. Exp.). 18: 63.

29. Lant, A. F., W. I. Baba, and G. M. Wilson. 1967. Localization of the site of action of oral diuretics on the human kidney. Clin. Sci. (London). 33: 11.

30. Widrow, S. H., and N. G. Levinsky. 1962. The effect of parathyroid extract on renal tubular reabsorption, of calcium in the dog. J. Clin. Invest. 41: 2151.

31. Frick, A., G. Rumrich, K. J. Ullrich, and W. G. Lassiter. 1965. Micro perfusion study of calcium transport in the proximal tubule of the rat kidney. Arch. Gesamte Physiol. Menschen Tiere (Pfluegers). 286: 109.

32. Massry, S. G., J. W. Coburn, L. W. Chapman, and C. R. Kleeman. 1968. Role of serum Ca, parathyroid hormone and $\mathrm{NaCl}$ infusion on renal $\mathrm{Ca}$ and $\mathrm{Na}$ clearances. Amer. J. Physiol. 214: 1403. 
33. Quinodoz, J. M., R. C. de Sousa, and A. F. Muller. 1965. Action du chlorthalidone (Hygroton) sur l'elimination urinaire et le taux sanguin du phosphore chez des sujets hypoparathyroidiens et normaux. Schweiz. Med. Wochenschr. 95 : 1706.

34. Caldwell, J. G., L. V. Avioli, and C. Boisseau. 1971. Hydrochlorothiazide and calcium homeostasis in idiopathic hypercalciuria. Clin. Res. 19: 676.

35. Harrison, A. R., and G. A. Rose. 1968. The effect of bendrofluazide on urinary and fecal calcium and phosphorus. Clin. Sci. (London). $34: 343$.

36. Gursel, E. 1970. Effects of diuretics on renal and intestinal handling of calcium. N. Y. State J. Med. 70: 399.

37. Donath, A., S. Nordio, F. Macagno, and R. Gatti. 1970. The effect of hydrochlorothiazide on calcium and strontium transport in intestine and kidney. Helv. Paediat. Acta. 25 : 293.

38. Sode, J., J. J. Sabol, C. R. Meloni, and J. J. Canary. 1969. Thiazide challenge in primary hyperparathyroidism. Clin. Res. $17: 550$.

39. Torsti, P., and B. Lamberg. 1964. Effect of two day treatment with chlorothiazide on urinary excretion of calcium, phosphate and sodium in hyper- and hypocalcemia. Acta Med. Scand. Suppl. 175 : 181.
40. Liberman, U. A., O. Sperling, A. Atsmon, M. Frank, M. Modan, and A. de Vries. 1968. Metabolic and calcium kinetic studies in idiopathic hypercalciuria. J. Clin. Invest. $47: 2580$.

41. Lafferty, F. W., and O. H. Pearson. 1963. Skeletal, intestinal, and renal calcium dynamics in hyperparathyroidism. J. Clin. Endocrinol. Metab. 23 : 891.

42. Bell, N. H., F. C. Bartter, and H. Smith. 1963. The effect of Vitamin D on $\mathrm{Ca}^{47}$ metabolism in man. Trans. Ass. Amer. Physicians Philadelphia. 76: 163.

43. Rasmussen, H., H. DeLuca, C. Arnaud, C. Hawker, and M. V. Steidingk. 1963. The relationship between Vitamin D and parathyroid hormone. J. Clin. Invest. 42: 1940.

44. Stote, R. M., W. J. Dube, D. M. Wilson, and L. H. Smith. 1971. The effect of hydrochlorothiazide on serum calcium and parathyroid hormone concentration in normal subjects. Clin. Res. 19: 686.

45. Sherwood, L. M., I. Herrman, and C. A. Bassett. 1970. Parathyroid hormone secretion in vitro: regulation by calcium and magnesium ions. Nature (London). 225: 1056.

46. Coe, F. L., J. M. Canterbury, and E. Reiss. 1971. Hyperparathyroidism in idiopathic hypercalciuria: primary or secondary? Clin. Res. 19: 571. 